\title{
KEPATUHAN APARATUR DESA DALAM PENATAUSAHAAN PENGELOLAAN KEUANGAN DESA BERDASARKAN PERATURAN MENTERI DALAM NEGERI NOMOR 113 DI WILAYAH KECAMATAN SAMBAS KABUPATEN SAMBAS
}

\author{
Yuliansyah $^{1}$ \\ Munandar ${ }^{2}$ \\ Prodi Akuntansi \& Bisnis \\ Politeknik Negeri Sambas \\ Email: yoelashshidiqie@gmail.com
}

\begin{abstract}
ABSTRAK
Penelitian ini berjudul Kepatuhan Aparatur Desa dalam Penatausahaan Pengelolaan Keuangan Desa Berdasarkan Peraturan Menteri Dalam Negeri Nomor 113 Tahun 2014 Di Wilayah Kecamatan Sambas Kabupaten Sambas. Tujuan penelitian ini untuk mengetahui kepatuhan penatausahaan yang telah dilakukan oleh pemerintah desa dengan Peraturan Menteri Dalam Negeri Nomor 113 Tahun 2014 tentang Pengelolaan Keuangan Desa dan peraturan perundangan-undangan yang berlaku. Metode penelitian yang digunakan dalam penelitian ini adalah metode deskriptif dengan pendekatan kualitatif. Hasil yang didapat dalam penelitian ini adalah penatausahaan keuangan desa yang berada wilayah Kecamatan Sambas cukup baik dan hampir seluruh desa yang diambil telah sesuai dengan Peraturan Bupati Nomor 13 Tahun 2015 Tentang Pedoman Pengelolaan Keuangan Desa sebagai bentuk implementasi atas Peraturan Menteri Dalam Negeri Nomor 113 Tahun 2014 Tentang Pengelolaan Keuangan Desa. Kendala yang dihadapi desa dalam melakukan penatausahaan keuangan berdasarkan Peraturan Menteri Dalam Negeri Nomor 113 Tahun 2014 diantaranya berupa kurang diadakannya bimbingan teknis serta pelatihan keuangan desa, kurang memadainya sumber daya manusia yang mengakibatkan beberapa desa tidak melaporkan laporan pertanggungjawaban sesuai dengan amanah peraturan perundang-undangan yang berlaku. Laporan pertanggungjawaban tersebut akan disampaikan kepada Badan
\end{abstract} Pemberdayaan Masyarakat Desa dan Pemerintah Desa.

Kata Kunci : AkuntansiPemerintahDesa, PenatausahaanDesa

\section{ABSTRACT}

The research title is the obidience of village administration office toward village financial management based on Domestic Ministry Decree No 113/2014. The objectives this research is to find out the obedience of village administration office, especially in Sambas district area, towardthe system of village finance management as regulated by Domestic Ministy No 113/2014.This research applied descriptise method with qualitative design. This research found that most of village administration offices of Sambas distric areas had followed and implemented the regulation of local goverment office No 13/2015 regarding the guideline of managing village financial system as decreed on Domestic Ministry Decree No 113/2014. The study aslo found that the village administration had narrow understanding on the some parts the financial system due to lack of technical quidence on village financial system and lack of adequate human resources of the office. As a result, some village administration did not make their financial report accordence with the regulation stated and the ministy of rural.

Keyword: Village of accounting government, Village of administration 


\section{PENDAHULUAN}

Pemerintahan Desa merupakan salah satu bentuk organisasi non profit yang bertujuan meningkatkan pelayanan kepada masyarakat umum yang berupa peningkatan keamanan, peningkatan kesehatan, peningkatan pembangunan, dan lain-lannya. Desa memiliki aspek sebagai lembaga ekonomi dikarenakan memiliki bentuk pengeluaran guna membiayai kegiatan-kegiatan yang dilakukan di satu sisi, dan di sisi lain harus melakukan berbagai upaya penghasilan guna menutupi seluruh biaya tersebut.

Sebagaimana halnya suatu instansi pemerintah yang lain, pemerintahan desa juga berusaha untuk mencegah atau menghindari pemborosan dan hal - hal yang di anggap merugikan karena hal - hal demikian akan membawa pengaruh buruk bagi keuangan desa. Untuk menjamin adanya akuntabilitas dalam pengelolaan keuangan, maka diperlukan suatu sistem akuntansi keuangan yang tepat untuk di terapkan. Sistem akuntansi keuangan merupakan suatu hal yang penting untuk diperhatikan dalam pemerintahan desa dikarenakan dapat digunakan sebagai alat pengatur kegiatan keuangan dan melindungi kekayaan milik desa.

Akuntansi keuangan desa merupakan salah satu bidang dalam akuntansi sektor publik yang mendapat perhatian besar dari pihak publik ataupun masyarakat. Dengan lahirnya UndangUndang Nomor 23 Tahun 2014 tentang Pemerintah Daerah yang mana telah diperbarui dengan Undang-Undang Nomor 9 Tahun 2015 menjelaskan bahwa daerah dapat menyelenggarakan otonomi daerah secara luas dan daerah diberikan kesempatan untuk mengurus daerah masing - masing, Undang-Undang Nomor 6 Tahun 2014 tentang Desa, dan Peraturan Pemerintah (PP) Nomor 71 Tahun 2010 tentang Standar Akuntansi Pemerintah, menjadi titik awal dimulainya sistem informasi pembangunan kawasan perdesaan. Dengan adanya otonomi daerah maka setiap daerah dapat mengatur kebutuhan daerah mereka sendiri, baik dari sisi perencanaan, pelaksanaan maupun pembangunan daerah yang mempunyai batas-batas wilayah yang berwenang mengatur dan mengurus urusan pemerintahan dan kepentingan masyarakat setempat menurut prakarsa sendiri berdasarkan aspirasi masyarakat. Peran serta warga masyarakat sangat penting untuk menyalurkan aspirasi, pemikiran, dan kepentingannya dalam penyelenggaraan Pemerintahan Daerah. Adanya Undang-Undang tersebut telah memberi kewenangan yang lebih luas kepada Desa tingkat kecamatan untuk menyelenggarakan semua urusan pemerintah mulai dari perencanaan, penganggaran, penatausahaan, pelaporan dan pengawasan, sehingga mendorong desa untuk lebih memberdayakan semua potensi yang dimiliki dalam rangka membangun dan mengembangkan desanya.

Maraknya pembahasan mengenai pengelolaan keuangan desa, terutama hubungannya dengan sistem pencatatan akuntansi dalam menyajikan penyusunan pelaporan keuangan yang masih belum sesuai dengan standar yang ditetapkan pemerintah. Kurangnya pengetahuan sumberdaya manusia yang menjadi penghambat dalam pengelolaan keuangan desa dan informasi yang dikelola oleh sistem tersebut masih cenderung lebih luas dan berbeda-beda ragam antar kabupaten yang sesuai dengan pembangunan di daerah masing-masing. Selain itu juga, masih banyak desa yang belum menatausahakan keuangan desa dengan sebagaimana mestinya. Informasi yang didapatkan belum akurat dan tepat waktu dalam rangka mendukung penyelenggaraan pengamanan transaksi melalui penatausahaan, pemrosesan dan pelaporan transaksi keuangan yang konsisten dalam menghasilkan informasi sebagai dasar pertanggungjawaban dan pengambilan keputusan sehingga menarik untuk dibahas. Peneliti melakukan penelitian di Kabupaten Sambas. 
Kabupaten ini menjadi menarik sebagai salah satu obyek penelitian karena minimnya sumberdaya manusia yang membidangi bidang akuntansi, tata kelola aparat pemerintah desa yang minim, sistem akuntabilitas dan pranata pengawasan yang masih lemah, serta ketidakpahaman dalam menyusun laporan keuangan. Dalam Pemerintahan Desa Kecamatan Sambas terdiri dari 18 desa dan ada 6 desa yang menjadi sampel penelitian yaitu Desa Lorong, Desa Sungai Rambah, Desa Jagur, Desa Lumbang,Desa Sumber Harapan, dan Desa Semangau. Desa yang berada wilayah Kecamatan Sambas Kabupaten Sambas mulai menerapkan Permendagri

\section{TELAAH LITERATUR 2.1 Kepatuhan}

Pranoto (2007) mengemukakan bahwa kepatuhan adalah perilaku yang sesuai aturan dan berdisiplin. Serta Notoatmodjo (2003) menyatakan bahwa kepatuhan merupakan suatu perubahan perilaku dari perilaku yang tidak menaati peraturan ke perilaku yang menaati peraturan. Dalam hal penatausahaan dan penyampaian laporan keuangan ke publik, perspektif instrumental menggambarkan bahwa insentif yang diperoleh perusahaan atau instansi bila menyampaikan laporan keuangannya dengan tepat waktu yaitu respon baik publik terhadap perusaaan itu sendiri, dan sebaliknya. Sedangkan untuk perspektif yang kedua, seorang individu cenderung untuk mematuhi ketentuan dalam hal ini ketepatan waktu pelaporan keuangan karena dianggap sebagai suatu keharusan (normative commitment through morality) dan karena otoritas penyusun ketentuan tersebut untuk mendikte perilaku untuk melaporkan keuangannya tepat pada waktu yangtelah ditentukan (normative commitment through legitimacy) dalam hal ini adalah Aparatur Desa. Teori kepatuhan dapat mendorong seseorang untuk lebih mematuhi peraturan yang berlaku, sama halnya dengan perusahaan atau instansi yang berusaha untuk menyampaikan
Nomor 113 Tahun 2014 efektifnya diberlakukan pada bulan Oktober Tahun 2015 pada proses pencairan dana tahap II dan tahap III. Kondisi Desa yang berada di Kecamatan Sambas di Tahun 2016 merupakan penerapan perubahan Peraturan Menteri Dalam Negeri mejadikan suatu masalah baru dalam pemerintahan desa. Oleh karena itu, peneliti tertarik untuk melakukan penelitian dengan mengangkat judul, "Kepatuhan Aparatur Desa dalam Penatausahaan Pengelolaan Keuangan Desa Berdasarkan Peraturan Menteri Dalam Negeri Nomor 113 Tahun 2014 Di Wilayah Kecamatan Sambas Kabupaten Sambas".

laporan keuangan secara tepat waktu karena selain merupakan suatu kewajiban perusahaan atau instansi untuk menyampaikan laporan keuangan tepat waktu, juga akan sangat bermanfaat bagi para pengguna laporan keuangan (Sulistyo, 2010).

Berdasarkan defenisi diatas tentang kepatuhan maka kepatuhan yang dimaksudkan dalam penelitian ini adalah kepatuhan aparatur desa dalam menatausahakan, menyampaikan serta mempertanggungjawabkan kegiatan Pengelolaan Keuangan Desa berdasarkan peraturan yang telah ditetapkan pemerintah berdasarkan Permendagri Nomor 113 Tahun 2014.

\subsection{Pemerintah Desa}

Menurut Undang - undang desa adalah kesatuan masyarakat hukum yang memiliki batas wilayah yang berwenang untuk mengatur dan mengurus urusan pemerintah, kepentingan masyarakat setempat berdasarkan prakarsa masyarakat, hak asal usul, dan / atau hak tradisional yang diakui dan dihormati dalam sistem pemerintahan Negara Kesatuan Republik Indonesia. Di desa juga dibentuk lembaga kemasyarakatan yang bertugas membantu pemerintahan desa dan memberdayakan masyarakat desa.Pemerintah Desa atau disebut juga Pemdes adalah lembaga 
pemerintah yang bertugas mengelola wilayah tingkat desa.Dalam pasal 25 Undang-Undang Nomor 6 Tahun 2014 Tentang Desa, Pemerintahan desaadalah kepala desa dan dibantu oleh perangkat desa serta dibantu oleh lembaga konsultatif atau Badan Permusyawaratan Desa (BPD). Perangkat Desa terdiri atas: sekretariat Desa; pelaksana kewilayahan; dan pelaksana teknis.

\subsection{Permendagri Nomor 113 Tahun 2014 tentang Pengelolaan Keuangan Desa}

Pengelolaan Keuangan Desa berdasarkan Permendagri 113 Tahun 2014 adalah keseluruhan proses kegiatan mulai dari Perencanaan, Pelaksanaan, Penatausahaan, Pelaporan, Pertanggungjawaban, serta Pembinaan dan Pengawasan keuangan desa. Keuangan desa dikelola berdasarkan asas-asas transparan, akuntabel, partisipatif serta dilakukan dengan tertib dan disiplin anggaran. Pengelolaan keuangan desa, dikelola dalam masa 1 tahun anggaran yakni mulai tanggal 1 Januari sampai dengan tanggal 31 Desember.

\subsection{Pelaksanaan Penatausahaan Menurut Permendagri No 113 Tahun 2014}

Kepala desa dalam melaksanakan penatausahaan keuangan desa harus menetapkan bendahara desa.Penetapan bendahara desa harus dilakukan sebelum dimulainya tahun anggaran bersangkutan dan berdasarkan keputusan kepala desa.Bendahara adalah perangkat desa yang ditunjuk oleh kepala desa untuk menerima, menyimpan, menyetorkan, menatausahakan, membayar, dan mempertanggungjawabkan keuangan desa dalam rangka pelaksanaan APBDes (Ardi Hamzah, 2015).

Menurut Permendagri No 113 Tahun 2014 Bendahara Desa wajib melakukan pencatatan melakukan setiap penerimaan dan pengeluaran serta melakukan tutup buku setiap akhir bulan secara tertib. Bendahara Desa wajib mempertanggungjawabkan uang melalui laporan pertanggungjawaban. Laporan pertanggungjawaban bendahara disampaikan setiap bulan kepada Kepala Desa dan paling lambat tanggal 10 bulan berikutnya. Penatausahaan penerimaan dan pengeluaran menggunakan: Buku Kas Umum, Buku Kas Harian Pembantu, Buku Kas Pajak Pembantu, dan Buku Bank Desa. Menurut Permendagri No 113 Tahun 2014 penatausahaan hanya terdiri dari buku-buku diatas dengan dilengkapi buktibukti transaksi. Selain itu bendahara dapat membuat laporan keuangan berupa neraca.Neraca menggambarkan posisi keuangan desa mengenai aktiva, kewajiban, dan modal dana pada satu periode. Pos-pos dalam neraca terbentuk dari transaksi-transaksi yang terjadi di desa.

\subsection{Pelaksanaan Penatausahaan Menurut Peraturan Bupati Sambas No 13 Tahun 2015}

Menurut pasal 49 Perbup Sambas No 13 Tahun 2015 Bendahara Desa wajib melakukan pencatatan melakukan setiap pendapatan dan belanja serta melakukan tutup buku setiap akhir bulan secara tertib.Bendahara Desa wajib mempertanggungjawabkan uang melalui laporan pertanggungjawaban yang disampaikan setiap bulan kepada Kepala Desa dan paling lambat tanggal 10 (sepuluh) bulan berikutnya.Penatausahaan pendapatan dan belanja desa menggunakan Buku Kas Umum, Buku Kas Pembantu Pajak, dan Buku Bank Desa.

Pencairan dana dalam rekening kas Desa ditandatangani oleh Kepala Desa dan Bendahara Desa. Setiap belanja desa dan pengeluaran pembiayaan dikeluarkan setelah mendapat persetujuan dari Kepala Desa dan dibukukan beserta bukti pengeluaran yang sah dan dapat dipertanggungjawabkan. 


\section{METODE PENELITIAN 3.1 Objek Penelitian}

Objek penelitian ini adalah persepsi responden mengenai penatausahaan pengelolaan keuangan desa yang dilakukan oleh aparatur desa yang diukur dari sisi Peraturan Menteri Dalam Negeri Nomor 113 Tahun 2014. Penelitian dilakukan terhadap para responden antara lain kepala desa, bendahara desa, sekretaris desa dan kepala seksi keuangan yang ada di Desa Lorong, Desa Sungai Rambah, Desa Jagur, Desa Lumbang, Desa Sumber Harapan, dan Desa Semangau Kecamatan Sambas; Kabupaten Sambas Tahun Anggaran 2016. Setiap desa yang diwawancarai minimal 2 orang responden.

\subsection{Bentuk Penelitian}

Penelitian ini mendeskipsikan gambaran yang senyatanya dari fenomena yang terjadi di pemerintahan desa khususnya kepatuhan aparatur desa dalam pengelolaan keuangan desa berdasarkan Permendagri Nomor 113 Tahun 2014 di wilayah Kecamatan Sambas, Kabupaten Sambas. Dilihat dari obyek dan metode analisis yang digunakan, maka penelitian ini termasuk dalam tipe penelitian deskriptif kualitatif.

Penelitian kualitatif merupakan sebuah cara yang lebih menekankan pada aspek pemahaman secara mendalam terhadap suatu permasalahan. Penelitian kualitatif ini adalah penelitian riset yang bersifat deskriptif dan cenderung menggunakan analisis serta lebih menonjolkan proses dan makna. Tujuan dari metodologi ini ialah pemahaman secara lebih mendalam terhadap suatu permasalahan yang dikaji dan data yang dikumpulkan lebih banyak kata ataupun gambar-gambar daripada angka-angka.

Menurut Moleong (2007 : 5) menyatakan bahwa penelitian kualitatif adalah pengumpulan data pada suatu latar alamiah, dengan menggunakan metode alamiah, dan dilakukan oleh orang atau peneliti yang tertarik secara alamiah. Berdasarkan pernyataan tersebut pendekatan yang digunakan dalam penelitian kualitatif menggunakan pendekatan alamiah atau fenomenalogi yang mana dimaksudkan untuk memhami respon atas keberadaan masyarakat dan pemahaman yang dipahami dalam berintekraksi. Oleh karena itu alamiah atau fenomenalogis digunakan untuk mengambarkan dan memaparkan bagaimana bentuk kepatuhan aparatur desa dalam penatausahaanpengelolaan keuangan desa berdasarkan Permendagri Nomor 113 Tahun 2014 di wilayah Kecamatan Sambas Kabupaten sambas.

\subsection{Teknik dan Alat Pengumpul Data}

\subsubsection{Teknik Pengumpul Data}

Pada setiap penelitian ini tentunya tidak terlepas dari penggunaan teknik danalat pengumpul data yang tepat. Dalam penelitian ini digunakan teknikpengumpulan data dengan teknik komunikasi langsung. Teknik komunikasilangsung merupakan teknik yang dilakukan dengan menggunakan wawancara yang dilakukan pada narasumber untuk mencari informasi yang jelas.

\subsubsection{Alat Pengumpul Data}

a. Wawancara

Wawancara adalah percakapan dengan maksud tertentu. Percakapan itu dilakukan oleh kedua belah pihak, yaitu pewawancara (interviuwer) yang mengajukan pertanyaan dari yang diwawancarai (interviewee) yang memberikan jawaban atas pertanyaan pewawancara itu.

\section{b. Pengamatan/Observasi}

Sebagai metode ilmiah observasi dapat diartikan sebagai pengamatan, meliputi pemusatan terhadap suatu objek dengan menggunakan panca indra. Jadi observasi merupakan suatu penyelidikan yang dilakukan dengan sengaja menggunakan alat indra terutama mata untuk melihat apakah barang yang tersedia sesuai apa tidaknya dengan yang tertera di kertas. 


\section{c. Metode Dokumentasi}

Metode dokumentasi adalah mencari data mengenai hal-hal atau variabel yang berupa catatan buku, surat, transkip, majalah, prasasti, notulen, agenda dan sebagainya. Metode dokumentasi ini digunakan untuk memperoleh data tentang mekanisme penatausahaan akuntansidan tentang peraturan perundang-undangan.

\subsection{Sumber Data}

Dalam penelitian ini, sumber data yang digunakan antara lain adalah:

\section{Data Primer}

Menurut Hasan (2002 : 82) menyatakan data primer adalah data yang diperoleh atau dikumpulkan langsung di lapangan oleh orang yang melakukan penelitian atau yang bersangkutan yang memerlukannya. Data primer di dapat dari sumber informan yaitu individu atau peseorangan seperti wawancara yang dilakukan oleh peneliti. Data primer ini antara lain:

1) Catatan hasil wawancara; dan

2) Data mengenai informan.

\section{Data Sekunder}

Menurut Hasan (2002 : 58) menyatakan bahwa data sekunder adalah data yang diperoleh atau dikumpulkan oleh orang yang melakukan penelitian dari sumber-sumber yang telah ada didapatkan. Data ini digunakan untuk mendukung informasi primer yang telah diperoleh yaitu dari bahan pustaka, literatur, penelitian terdahulu, buku, dan lain sebagainya.

Adapun sumber data pada penelitian ini adalah sumber data primer, di mana data yang diperoleh merupakan data yang diperoleh secara langsung selama dua tahun sejak di berlakukan Undang-Undang Desa, artinya data-data tersebut didapat pada informan langsung di wilayah tersebut yang masih belum di olah atau disajikan oleh pihak-pihak lain.

\subsection{Teknik Analisis Data}

Analisis data adalah langkah terakhir sebelum melakukan penarikan kesimpulan. Menurut Moh (2010: 119) analisis data dari hasil pengumpulan data merupakan proses yang penting dalam penyelesaian suatu kejadian seuatu kegiatan penelitian ilmiah. Penelitian ilmiah yang dimaksudkan, karena dari analisis data akan didapatkan arti dan makna dalam memecahkan masalahmasalah yang diteliti.

Data yang akan dianalisis dalam penelitian ini menggunakan metode kualitatif dimana analisis ini disajikan dalam bentuk pernyataan dan uraian yang akan disusun secara sistematis. Data yang terkumpul selama melakukan penelitian maka peneliti mengklasifikasi, analisis, dan interpretasi secara detail, cermat dan teliti untuk memperoleh kesimpulan yang lebih obyektif dari suatu penelitian. Analisis data dalam penelitian ini dilakukan secara mendalam sebagai upaya mencari dan menata secara sistematis catatan hasil observasi, wawancara dan informasi lainnya dalam meningkatkan pemahaman peneliti tentang kasus yang diteliti. Proses analisis dalam penelitian ini dilakukan dengan empat tahap, yaitu

$$
\text { 1. Pengumpulan Data }
$$

Pengumpulan data diperoleh dari hasil wawancara kepada pejabat pengelola keuangan desa dan dokumentasi yang didapat dari literatur-literatur dan sumber internet. Selama proses pengumpulan data berlangsung, peneliti melakukan proses pengalisisan data yang benar-benar diperlukan.

\section{Pengkasifikasian Data}

Pengklasifikasian data dilakukan untuk memilih data yang relevan dan bermakna, memfokuskan data yang mengarah untuk memecahkan dan menyelesaikan masalah, penemuan, pemaknaan serta untuk menjawab pertanyaan penelitian. Setelah itu dilakukan penyederhanaan dan 
menyusun secara sistematis serta menjabarkan hal-hal yang penting tentang hasil temuan dan makna dari temuan tersebut.

\section{Penyajian Data}

Penyajian data dilakukan untuk menggabungkan informasi sehingga menggambarkan atau menjelaskan keadaan yang terjadi bisa berbentuk tulisan dan kata-kata.

4. Penarikan Kesimpulan

Penarikan kesimpulan merupakan penarikan dari data yang tampil dengan melibatkan pemahaman peneliti. Penarikan kesimpulan dalam penelitian kualitatif dilakukan sejak awal data di kumpulkan, proses reduksi data, setelah data terkumpul cukup memadai, selanjutnya diambil kesimpulan sementara, dan setelah data benar-benar lengkap maka diambil kesimpulan akhir sesuai dengan masalah.

\section{HASIL PENELITIAN DAN PEMBAHASAN}

\subsection{Hasil Penelitian}

\subsubsection{Penatausahaan Pengelolaan Keuangan Berdasarkan Permendagri No. 113 Tahun 2014}

Menurut Permendagri No 113 Tahun 2014 Bendahara Desa wajib melakukan pencatatan melakukan setiap penerimaan dan pengeluaran serta melakukan tutup buku setiap akhir bulan secara tertib. Bendahara Desa wajib mempertanggungjawabkan uang melalui laporan pertanggungjawaban. Laporan pertanggungjawaban bendahara disampaikan setiap bulan kepada Kepala Desa dan paling lambat tanggal 10 bulan berikutnya. Penatausahaan penerimaan dan pengeluaran menggunakan:
a. Buku Kas Umum
b. Buku Kas Harian Pembantu
c. Buku Kas Pajak Pembantu
d. Buku Bank Desa
e. Neraca Desa ( Laporan Kekayaan Desa)

f. Laporan Realisasi Anggaran Pendapatan Dan Belanja Desa (LRADes)

\subsubsection{Penatausahaan Pengelolaan Keuangan di Kecamatan Sambas Kabupaten Sambas}

Pemerintah desa di wilayah Kecamatan Sambas Kabupaten Sambas secara umum memiliki sumber daya yang masih minim, sehingga berpengaruh pada hasil dari proses pengelolaan keuangan yang dibuat hanya memuat Rancangan Anggaran Pendapatan dan Belanja Desa (APBDesa) dan Laporan Pertanggungjawaban ADD seperti Buku Kas Umum, Buku Kas Pembantu Pajak, dan Buku Bank.

Proses akuntansi pemerintah desa dalam bentuk laporan pertanggungjawaban ADD yang telah dibuat dan dilaporkan pertanggungjawaban keuangan tersebut diambil 6 (Enam) desa sebagai sampel penelitian dari 18 (delapan belas) desa yang termasuk di Kecamatan Sambas adalah sebagai berikut:

\section{Desa Desa Lorong}
a. Laporan Realisasi Anggaran Pendapatan dan Belanja Desa (APBDesa)

b. Buku Kas Umum Semester II

c. Buku Kas Pembantu Kegiatan

d. Buku Bank Desa

\section{Desa Sungai Rambah}

a. Laporan Realisasi Anggaran Pendapatan dan Belanja Desa (APBDesa)

b. Buku Kas Umum Semester I

c. Buku Kas Umum Semster II

d. Buku Kas Pembantu Pajak

e. Buku Kas Pembantu Kegiatan

f. Buku Kas Harian Pembantu

g. SPJ Belanja

h. SPP

i. Laporan Realisasi Penggunaan Dana Desa

j. Buku Bank Desa

k. Laporan Kekayaan Milik Desa Tahun 2015

1. Laporan Pertanggungjawaban Bendahara Desa 
m. Laporan Pertanggungjawaban Realisasi Pelaksanaan APBDes Tahun 2016

\section{Desa Jagur}

a. Laporan Realisasi APBDes

b. Buku Kas Umum Tahap II

c. Buku Kas Pembantu Kegiatan

d. Laporan Realisasi Penggunaan Dana Desa Tahap I

e. Laporan Realisasi Penggunaan Dana Desa Tahap II

\section{Desa Lumbang}

a. Laporan Realisasi APBDesa

b. Buku Kas Umum Tahap II

c. Buku Kas Harian Pembantu

d. Buku Pembantu Kegiatan

e. Buku Kas Pembantu Pajak

f. Buku Bank Desa

g. Laporan Realisasi Penggunaan Dana Desa

h. Laporan Kekayaan Milik Desa

\section{Desa Semangau}

a. Laporan Realisasi APBDesa

b. Buku Kas Umum Tahap II

c. Buku Kas Pembantu Pajak

d. Buku Kas Harian Pembantu

e. Buku Bank Desa

f. Buku Kas Pembantu Kegiatan

g. Laporan Realisasi Penggunaan Dana Desa

6. Desa Sumber Harapan

a. Buku Bank Desa

b. Buku Kas Umum

c. Buku Kas Pembantu Pajak

d. Laporan Realisasi APBDesa

e. Buku Kas Harian Pembantu

f. RPD Tahap I

g. RPD Tahap II

h. SPP

i. SPJ Belanja

\subsection{Pembahasan}

\subsubsection{Penatausahaan Pengelolaan} Keuangan Pemerintah Desa yang Dilakukan Aparatur Desa di Wilayah Kecamatan Sambas Kabupaten Sambas Berdasarkan dengan Permendagri Nomor 113 Tahun 2014.
Hasil penelitian mengenai laporan keuangan yang telah dibuat oleh 6 (enam) desa yang disajikan dalam Laporan Pertanggungjawaban ADD yang dijadikan tolak ukur kemampuan aparatur desa dalam penerapan Permendagri No 113 tahun 2014 tentang Pengelolaan Keuangan Desa. Adapun proses penatausahaan yang telah dilakukan oleh 6 (enam) desa di wilayah Kecamatan Sambas kabupaten Sambas dapat dilihat pada tabel 4.1.

Tabel 4.1

Hasil Rekapitulasi dari Setiap Desa yang Diteliti

\begin{tabular}{|c|c|c|c|}
\hline No & $\begin{array}{l}\text { Penatausahaa } \\
\text { n Menurut } \\
\text { Permendagri } \\
113 \text { Tahun } \\
2014\end{array}$ & $\begin{array}{c}\text { Nama-Nama } \\
\text { Desa yang } \\
\text { Patuh }\end{array}$ & $\begin{array}{l}\text { Nama-Nama } \\
\text { Desa yang } \\
\text { Tidak Patuh }\end{array}$ \\
\hline 1 & $\begin{array}{l}\text { Buku } \\
\text { Umum }\end{array}$ & $\begin{array}{l}\text { Semua desa } \\
\text { patuh }\end{array}$ & - \\
\hline 2 & $\begin{array}{l}\text { Buku Kas } \\
\text { Harian } \\
\text { Pembantu }\end{array}$ & $\begin{array}{l}\text { Sungai } \\
\text { Rambah, } \\
\text { Lumbang, } \\
\text { Sumber } \\
\text { Harapan dan } \\
\text { Semangau }\end{array}$ & $\begin{array}{l}\text { Lorong dan } \\
\text { Jagur }\end{array}$ \\
\hline 3 & $\begin{array}{l}\text { Buku Kas } \\
\text { Pembantu } \\
\text { Pajak }\end{array}$ & $\begin{array}{l}\text { Sungai } \\
\text { Rambah, } \\
\text { Lumbang, } \\
\text { Sumber } \\
\text { Harapan dan } \\
\text { Semangau }\end{array}$ & $\begin{array}{l}\text { Lorong dan } \\
\text { Jagur }\end{array}$ \\
\hline 4 & $\begin{array}{l}\text { Buku Bank } \\
\text { Desa }\end{array}$ & $\begin{array}{l}\text { Lorong, } \\
\text { Sungai } \\
\text { Rambah, } \\
\text { Lumbang, } \\
\text { Semangau, } \\
\text { dan Sumber } \\
\text { Harapan }\end{array}$ & Jagur \\
\hline 5 & $\begin{array}{l}\text { Laporan } \\
\text { Kekayaan } \\
\text { Desa }\end{array}$ & $\begin{array}{l}\text { Sungai } \\
\text { Rambah dan } \\
\text { Lumbang }\end{array}$ & $\begin{array}{l}\text { Lorong, } \\
\text { Semangau, } \\
\text { Sumber } \\
\text { Harapan dan } \\
\text { jagur }\end{array}$ \\
\hline 6 & LRADesa & $\begin{array}{l}\text { Semua desa } \\
\text { patuh }\end{array}$ & - \\
\hline
\end{tabular}

Sumber: Hasil Olahan Data 
Berdasarkan hasil wawancara dan data yang diperoleh bahwa penatausahaan penerimaan sudah sesuai dengan apa yang telah ditetapkan oleh Permendagri No 113 tahun 2014, membuat buku kas umum, buku kas harian pembantu, buku kas pembantu pajak, dan buku bank. Tetapi masih ada beberapa desa yang tidak membuat untuk penatausahaan laporan kekayaan desa (neraca), dari data yang di dapat desa-desa sudah mulai menerapkan membuat laporan kekayaan desa hanya 2 (dua) desa antara lain Desa Sungai Rambah dan Desa Lumbang.

Hasil dari penelitian yang dilakukan peneliti bahwa Aparatur Desa di wilayah Kecamatan Sambas Kabupaten Sambas dinilai cukup baik dalam menerapkan dan mematuhi sebagaimana yang ditetapkan dalam Peraturan Menteri Dalam Negeri Nomor 113 Tahun 2014 tentang Pengelolaan Keuangan Desa, walaupun masih ada beberapa desa yang kurang patuh dalam proses penatausahaan yang benar. Adapun desa yang kurang patuh dalam penatausahaan penerimaan dalam pengelolaan keuangan desa adalah Desa Lorong dan Desa Jagur.

\subsubsection{Kendala-Kendala yang Dihadapi Pemerintah Desa dalam Pengelolaan Keuangan Desa dalam Menerapkan Permendagri Nomor 113 Tahun 2014 Tentang Pengelolaan Keuangan Desa.}

Kendala yang dihadapi aparatur desa dalam penerapan Peraturan Menteri Dalam Negeri Nomor 113 Tahun 2014 tentang Pengelolaan Keuangan Desa dapat di sampaikan pada hasil penelitian dilapangan, maka peneliti mengelompokan kendala didalam penatausahaan pengelolaan keuangan desa menjadi 6 (enam) kendala dapat dilihat pada tabel 4.2.
Tabel 4.2

Kendala yang Dihadapi Pemerintah

Desa

\begin{tabular}{|l|l|l|l|l|l|l|}
\hline KET & $\begin{array}{l}\text { SD } \\
\text { M }\end{array}$ & $\begin{array}{l}\text { Pel } \\
\text { atih } \\
\text { an }\end{array}$ & $\begin{array}{l}\text { Apli } \\
\text { kasi } \\
\text { Aku } \\
\text { ntan } \\
\text { si }\end{array}$ & $\begin{array}{l}\text { Tim } \\
\text { Penda } \\
\text { mping }\end{array}$ & $\begin{array}{l}\text { Keterla } \\
\text { mbatan } \\
\text { Pencair } \\
\text { an dana }\end{array}$ & $\begin{array}{l}\text { Kom } \\
\text { unik } \\
\text { asi } \\
\& \\
\text { Infor } \\
\text { masi }\end{array}$ \\
\hline Lorong & $\checkmark$ & $\checkmark$ & & $\checkmark$ & $\checkmark$ & $\checkmark$ \\
\hline $\begin{array}{l}\text { Sungai } \\
\text { Rambah }\end{array}$ & & & $\checkmark$ & & & \\
\hline Jagur & $\checkmark$ & $\checkmark$ & $\checkmark$ & $\checkmark$ & $\checkmark$ & $\checkmark$ \\
\hline $\begin{array}{l}\text { Lumban } \\
\text { g }\end{array}$ & & & & $\checkmark$ & & $\checkmark$ \\
\hline $\begin{array}{l}\text { Semanga } \\
\text { u }\end{array}$ & $\checkmark$ & & $\checkmark$ & $\checkmark$ & & \\
\hline $\begin{array}{l}\text { Sumber } \\
\text { Harapan }\end{array}$ & & $\checkmark$ & $\checkmark$ & $\checkmark$ & & $\checkmark$ \\
\hline
\end{tabular}

\section{Sumber: Hasil Olahan Wawancara dengan Aparatur Desa di Kecamatan Sambas}

a) Sumber Daya Manusia

Berdasarkan hasil wawancara yang dilakukan peneliti dengan para informan dapat diketahui bahwa dari sampel yang di dapatkan hampir semuapemerintah desa di wilayah Kecamatan Sambas yang minimnya pejabat pelaksanaan pengelola keuangan desa yang benar-benar paham dengan proses penatausahaannya. Hal tersebut dikarenakan minimnya latar belakang pendidikan dari aparatur desa tersebut yang mempengaruhi kemampuan aparatur desa untuk menyelesaikan dan mengidentifikasi masalah yang di temukan dengan baik dan tepat seperti masalah penelaahan peraturan perundang-undangan yang selalu berubah-ubah dalam waktu yang singkat.

Menurut salah satu informan dari Desa Jagur keterbatasan kemampuan sumber daya manusia khususnya tenaga dibagian akuntansi dan seringnya terjadi 
mutasi dibagian bendahara sehingga memerlukan waktu untuk penyesuain dalam pekerjaan .

Menurut Kepala Desa Sungai Rambah, Sumber daya manusia yang berada di pemerintahan desa mayoritas lulusan Pendidikan SMA dan Sarjana selain Sarjana Ekonomi dan Akuntansi, sehingga memberikan dampak pada kegiatan pengelolaan keuangan desa baik dari perencanaan dan penatausahaannya dalam hal pencatatan akuntansi yang mana merupakan kualitas dari laporan keuangan desa yang baik dan benar.

b) Pelatihan

Berdasarkan hasil wawancara yang peneliti lakukan kepada informan seperti desa Lorong, Jagur, Sumber Harapan yang terkait dengan proses pengelolaan keuangan desa masih mempunyai kurangnya pelatihan yang diberikan oleh pihak Kabupaten/Kota dan Provinsi sehingga aparatur desa masih belum memahami secara terperinci masalah proses pengelolaan keuangan desa dengan baik. Adapun pelatihan yang diberikan hanya berupa bimbingan teknis saja tidak secara langsung kepada teknik yang benar. Seperti kita ketahui masih banyak aparatur desa yang masih kurang paham dalam penyusunan pajak dalam penatausahaan proses pengelolaan keuangan desa.

c) Aplikasi Akuntansi

Berdasarkan hasil wawancara yang dilakukan peneliti dengan para informan di Desa Sebayan dapat diketahui bahwa tidak adanya aplikasi pendukung dalam penyelenggaraan pemerintah desa, padahal yang pengelolaan keuangan saat ini di tingkat Kabupaten dan Provinsi adalah menggunakan aplikasi yang dibuat oleh Depkeu/Depdagri yaitu, SIKD/SIPKD. Menurut salah satu informan yang merupakan bendahara di Desa Sebayan yang berada di Kecamatana Sambas yang pernah mengikuti pelatihan proses pengelolaan keuangan desa, pernah di kenalkan dengan aplikasi yang akan mempermudah desa dalam penyusunan/pencatatan keuangan desa. Aplikasi yang dikenal yaitu SIMPEKDES, tetapi sampai saat ini belum berjalan optimal disebabkan kurang/minimnya tenaga ahli dalam pemberian bimbingan teknis kepada aparatur desa khususnya dalam tenaga pengelolaan keuangan di Pemerintah Desa.

Menurut salah satu informan dari Desa Semangau, Tahun 2017 ini baru diterapkan aplikasi akuntansi yang berbasis komputer yaitu SIMAPBDes, untuk mempermudah sumber daya manusia khususnya tenaga dibagian akuntansi dalam menyelesaikan pentausahaan pengelolaan keuangan desa khususnya dalam penyusunan laporan keuangan desa.

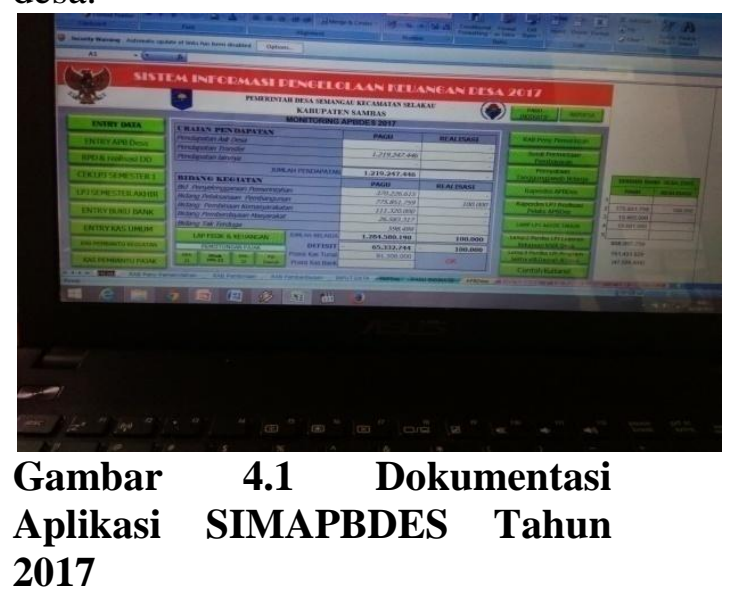

Pemerintah harus memberdayakan aparatur desa dengan menerapkan hasil pengembangan ilmu pengetahuan dan teknologi sehingga memicu kemajuan kemampuan dari aparatur desa dalam memanfaatkan teknologi sebaik mungkin sehingga mempermudah kegiatan pencatatan pengelolaan keuangan desa dengan cepat. 
d) Tim Pendamping

Berdasarkan hasil wawancara yang dilakukan peneliti kepada informan di Desa Lorong, Jagur, Lumbang, Semangau, dan Sumber Harapan untuk tahun 2016 tim pendamping yang direkrut oleh pemerintah untuk menjadi tim pendamping desa. Satu orang pendamping desa mewakili 6 (enam) desa, sehingga apabila terdapat masalah di Pemerintahan Desa tidak bisa diselesaikan dengan baik, dikarenakan kebanyakan tidak memiliki latar belakang yang sesuai dengan tugas pokok, fungsi \& kewenangannya.

e) Keterlambatan Pencairan Dana

Berdasarkan hasil wawancara yang dilakukan oleh peneliti kepada informan di Desa Lorong, dan Jagur bahwa penyebab proses penatausahaan desa, yakni terlambatnya ketelambatan pencairan dana, sehingga banyak program-program kegiatan yang direncanakan terlambat dalam pelaksanaannya. Hal itu juga, berakibat pada terlambatnya laporan pertanggungjawaban ke pihak Kecamatan dan Kabupaten sehingga berdampak terhadap proses pencairan dana tahap berikutnya.

f) Komunikasi dan Informasi

Berdasarkan hasil wawancara yang dilakukan oleh peneliti kepada informan di Desa Lorong dan Jagur bahwa komunikasi dan informasi merupakan kendala dalam proses penatausahaan pengelolaan keuangan desa dikarenakan komunikasi aparatur desa dengan pihak kabupaten tidak maksimal. Informasi yang didapatkan juga kurang akurat sehingga menjadi penghambat atau kendala dalam proses pengelolaan keuangan desa.

\section{KESIMPULAN DAN SARAN}

\subsection{Kesimpulan}

Berdasarkan hasil penelitian dan pembahasan yang telah diuraikan pada bab sebelumnya, maka dalam penulisan tugas akhir ini dapat ditarik kesimpulan sebagai berikut:

1. Penatausahaan pengelolaan keuangan desa yang dilakukan oleh pemerintah desa di wilayah Kecamatan Sambas Kabupaten Sambas dinilai cukup baikdan telah sesuai dengan Permendagri No. 113 Tahun 2014, hal ini didasarkan pada dalam menerapkan dan mematuhi sebagaimana yang ditetapkan dalam Peraturan Menteri Dalam Negeri Nomor 113 Tahun 2014 tentang Pengelolaan Keuangan Desa, hampir semua desa yang berada di wilayah Kecamatan Sambas patuh dalam penatausahaan yang benar. Kepatuhan atau kesesuaian dengan Permendagri No 113 Tahun 2014 menjadi tolak ukur bagi pemerintah desa dalam penatausahaan pengelolaan keuangan desa untuk tahun berikutnya. Dilihat dari hasil pembahasan dan penelitian diatas penulis dapat menyimpulkan bahwa pemerintah desa di wilayah Kecamatan Sambas Kabupaten Sambas cukup baik dalam mematuhi dan menerapkan Permendagri No. 113 Tahun 2014 tentang pengelolaan keuangan desa khusunya dalam penatausahaan keuangan desa baik dari segi pelaksana dan pelaksanaan penatausahaan.

2. Kendala-kendala yang dihadapi pemerintah desa di wilayah Kecamatan Sambas Kabupaten Sambas dalam penatausahaan pengelolaan keuangan desa dalam penerapan Permendagri No. 113 Tahun 2014 yaitu minimnya sumber daya manusia di pemerintah desa yang menyebabkan banyaknya pejabat pelaksanaan pengelola keuangan desa yang benar-benar paham dengan proses penatausahaannya. Hal tersebut dikarenakan minimnya latar belakang pendidikan dari aparatur desa tersebut yang mempengaruhi kemampuan aparatur desa untuk menyelesaikan dan mengidentifikasi masalah yang di temukan dengan baik dan tepat. Kurangnya pelatihan yang diberikan oleh pihak Kabupaten/Kota dan Provinsi sehingga aparatur desa masih belum memahami secara terperinci 
masalah proses pengelolaan keuangan desa dengan baik. Adapun pelatihan yang diberikan hanya berupa bimbingan teknis saja tidak secara langsung kepada teknik yang benar, seperti kurangnya pamahaman aparatur desa dalam penyusunan pajak dalam penatausahaan pengelolaan keuangan desa. Selain itu juga, belum adanya tim pendamping yang direkrut oleh pemerintah untuk menjadi tim pendamping desa di wilayah Kecamatan Sambas Kabupaten Sambas Tahun Anggaran 2016, kebanyakan tim pendamping tidak memiliki latar belakang yang sesuai dengan tugas pokok, fungsi \& kewenangannya.

\subsection{Saran}

Berdasarkan uraian kesimpulan dan hasil penelitian di atas, maka dapat diberikan saran-saran yang nantinya diharapkan dapat memperbaiki dan menyempurnakan penatausahaan pengelolaan keuangan desa pada pemerintahan desa di wilayah Kecamatan Sambas Kabupaten Sambas untuk tahun anggaran berikutnya. Adapun saran yang penulis berikan kepada pemerintah desa di wilayah Kecamatan Sambas Kabupaten Sambas antara lain

1. Agar sumber daya manusia di pemerintahan desa lebih kompeten dan professional maka pemerintah desa harus lebih sering melakukan pelatihan penatausahaan pengelolaan keuangan desa secara berkala.

2. Selain diberikan pelatihan, aparatur desa harus diberikan reward kepada aparatur yang dinilai baik hasil kinerjanya. Hal ini bertujuan untuk mendorong motivasi-motivasi bagi pemerintah desa yang lainnya di wilayah Kecamatan Sambas. Supaya meningkatkan kualitas atas penyusunan dan pelaporan pertanggungjawaban keuangan.

3. Desa-desa tersebut di Kecamatan Sambas Kabupaten Sambas dapat menjadi desa mandiri

Dengan saran yang telah dikemukakan diatas, penulis berharap kebijakan pengelolaan keuangan desa lebih baik lagi dan mewujudkan penatausahaan yang baik dan pembangunanan yang merata bagi masyarakat pedesaan di Kalimantan Barat.

\section{DAFTAR PUSTAKA}

Ardi Hamzah. (2015). Akuntansi Desa.Yogyakarta : Salemba Empat

Hasan. (2002a,2002b). Analisa Data Dengan Statistik. Jakarta : PT Bumi Aksara

Moh. (2010). Metode Penelitian. Jakarta : Ghalia Indonesia

Moleong. (2007).Metodologi Penelitian Kualitatif. Bandung : PT Remaja Rosdakarya

Pranoto. (2007). Ilmu Kepatuhan Kebidanan. Yogyakarta : Yayasan Bina Pustaka Sarwono Prawirohardjo

Sugiyono. (2010).Metode Penelitian kualitatif Kuantitatif. Bandung : Alfabeta

Sulistyo.(2010). "Kepatuhan Terhadap Ketepatan Waktu dalam Penyampaian Laporan Keuangan Tahunan (Study Kasus pada Bapepam)". Skripsi. Bandung : Fakultas Ekonomi Universitas Widyatama

Undang-Undang Nomor 9 Tahun 2015 tentang Pemerintah Daerah

Undang-Undang Nomor 6 Tahun 2014 tentang Desa

Peraturan Pemerintah Nomor 43 Tahun 2014 tentang Peraturan Pelaksanaan Undang-Undang Nomor 6 Tahun 2014

Peraturan Menteri Dalam Negeri Nomor 113 Tahun 2014 tentang Pengelolaan Keuangan Desa

Peraturan Menteri Dalam Negeri Nomor 84 Tahun 2015 tentang Struktur Organisasi dan Tata Kerja Pemerintah Desa

Peraturan Bupati Sambas Nomor 13 Tahun 2015 tentang Pedoman Pengelolaan Keuangan Desa 